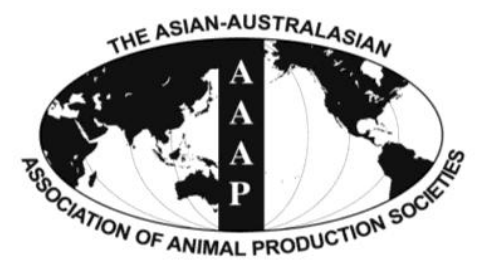

Asian Australas. J. Anim. Sci.

Vol. 26, No. 9 : 1347-1358 September 2013

http://dx.doi.org/10.5713/ajas.2013.13082

www.ajas.info

pISSN 1011-2367 elSSN 1976-5517

\title{
Perspective of Membrane Technology in Dairy Industry: A Review
}

\author{
Pavan Kumar ${ }^{1, a}$, Neelesh Sharma ${ }^{2,3, a}$, Rajeev Ranjan ${ }^{4}$, Sunil Kumar ${ }^{5}$, Z. F. Bhat ${ }^{5}$, and Dong Kee Jeong ${ }^{2, *}$ \\ ${ }^{1}$ Department of Livestock Product and Technology, College of Veterinary Science, \\ Guru Angad Dev Veterinary and Animal Sciences University, Ludhiana, Punjab, India
}

\begin{abstract}
Membrane technology has revolutionized the dairy sector. Different types of membranes are used in the industry for various purposes like extending the shelf life of milk without exposure to heat treatment, standardization of the major components of milk for tailoring new products as well increasing yield and quality of the dairy products, and concentrating, fractionation and purification of milk components especially valuable milk proteins in their natural state. In the cheese industry, membranes increase the yield and quality of cheese and control the whey volume, by concentrating the cheese milk. With the advancement of newer technology in membrane processes, it is possible to recover growth factor from whey. With the introduction of superior quality membranes as well as newer technology, the major limitation of membranes, fouling or blockage has been overcome to a greater extent. (Key Words: Membrane Filtration, Demineralization, Concentrating, Fractionation, Milk Purification)
\end{abstract}

\section{INTRODUCTION}

The term "membrane technology" is used to collectively represent the separation processes by employing specific semi-permeable membrane filters to concentrate or fractionate a liquid into two liquids of different compositions (Winston and Sirkar, 1992) by selectively allowing some compounds to pass while encumbering the others. The liquid that is able to pass the membrane is known as "permeates" and the retained liquid is known as "retentate" or "concentrate". The efficiency of membranes is largely governed by the hydrostatic pressure gradients

\footnotetext{
* Corresponding Author: Dong Kee Jeong. Tel: +82-64-754-3331, Fax: +82-64-725-2403, E-mail: newjdk@ gmail.com

${ }^{2}$ Department of Animal Biotechnology, Faculty of Biotechnology, Jeju National University, Jeju, Korea.

${ }^{3}$ Department of Veterinary Medicine, Faculty of Veterinary Science and Animal Husbandry, Sher-e-Kashmir University of Agricultural Sciences and Technology of Jammu, R.S.Pura, Jammu, (J \& K), India.

4 Department of Veterinary Pharmacology and Toxicology, College of Veterinary Science, LLRUVAS, Hissar, Haryana125001, India.

${ }^{5}$ Department of Livestock Product and Technology, Faculty of Veterinary Science and Animal Husbandry, Sher-e-Kashmir University of Agricultural Sciences and Technology of Jammu, R.S.Pura, Jammu, (J \& K), India.

${ }^{\text {a }}$ Equal contribution from both authors.

Submitted Feb. 1, 2013; Accepted Apr. 23, 2013; Revised Jun. 5, 2013
}

(also known as "transmembrane pressure") across the membrane and concentration gradient of the liquids. In few a cases, electric potential has important role (Winston and Sirkar, 1992).

The milk is considered as the best, ideal and a complete food and has an important place in human diet especially in vegetarian diet (Kumar and Rai, 2010; Shekhar et al., 2010; Kumar et al., 2011b; Shekhar and Kumar, 2011). The milk is an ideal liquid for membrane filtration due to its composition. Membrane technology has been applied in the dairy industry since the early 1960s and now comes the second behind the water treatment technology and serves as viable alternatives for more traditional dairy processes like distillation, evaporation or extraction. The food industry represents 20 to $30 \%$ of the current 250 million turnover of membranes worldwide with $7.5 \%$ annual growth. Several hundreds of thousand square meters of membrane (Ultrafiltration: 400,000; Nanofiltration: 300,000; Reverse osmosis: 100,000; Microfiltration: 50,000) are currently operating (Saxena et al., 2009). About $2 / 3$ of the membrane area installed in the dairy industry is used for the treatment of whey and about 1/3 for milk (Saxena et al., 2009). The utilization of membranes in dairy industry has been greatly enhanced with the introduction of novel base materials viz. cellulose acetate, polyamides, polysulphons accompanied by newer technological processes such as reverse osmosis, diafiltration (DF) and nanofiltration (NF) (Figure 1). In the present scenario, different types of membrane separation 


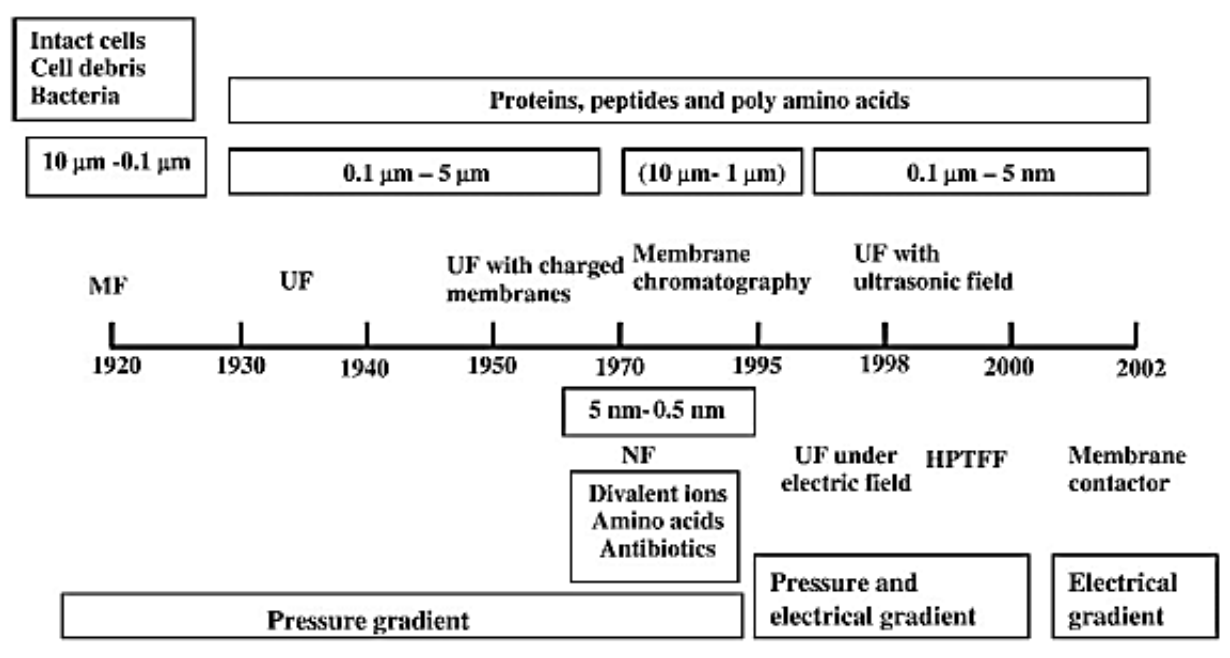

Figure 1. Milestones in the development of membrane technologies for protein separation/purification (Adopted from Saxena et al., 2009).

technologies such as micro-filtration, ultra-filtration (Balannec et al., 2005), nano-filtration (Vourch et al., 2005) and reverse osmosis (RO) (Balannec et al., 2005; Vourch et al., 2005) are being made available for use in the dairy industry.

The use of membrane filtration technology offers a wide range of advantages for the consumer as well as for the producers. The membrane technology is a novel non thermal environmental friendly greener technology with full of future possibilities that minimizes the adverse effect of temperature rise such as change in phase, denaturation of proteins and change in sensory attributes of the product. The membranes remove unwanted components viz. microorganisms, drugs or sediments that have a negative impact on product quality, making the final product more attractive in texture and increasing its shelf life. The selectivity of membranes is very high due to the unique mechanisms of action such as ion exchange, solution diffusion, etc. The membranes are suitable to different types of plant design and expansion due to their compact design and need very low maintenance. The operations of the membranes are very simple, competitive and do not required any specialized knowledge to handle or operate them. To get the desired effect, it is sometimes necessary to use a combination of membranes rather than single membrane (Balannec et al., 2005; Vourch et al., 2005) and redesigning overall industrial production by the integration of various already developed membrane operations (Saxena et al., 2009).

\section{CHARACTERISTICS OF MEMBRANE}

Microfiltration (MF) is a membrane separation process similar to ultrafiltration (UF) but with even larger membrane pore size allowing particles in the range of 0.2 to 2 micrometers to pass through. The pressure used is generally lower than that of UF process. MF membranes are especially well suited for the separation of fine particles in the size range of 0.1 to $10.0 \mu \mathrm{m}$ whereas UF membranes with 1 to $100 \mathrm{~nm}$ pore size were designed to provide high retention of proteins and other macromolecules (Van Reis et al., 2007). UF is a variety of membrane filtration in which hydrostatic pressure forces a liquid against a semipermeable membrane. Suspended solids and solutes of high molecular weight are retained, while water and low molecular weight solutes pass through the membrane. It is a separation/fractionation process using a 10,000 MW cutoff, $40 \mathrm{psig}$, and temperatures of 50 to $60^{\circ} \mathrm{C}$ with polysulfone membranes. Nanofiltration (NF) is a type of reverse osmosis where the membrane has a slightly more open structure allowing monovalent ions to pass through the membrane and rejecting the divalent ions to a great extent. $\mathrm{RO}$ is a high pressure-driven membrane filtration process which is based on a very dense membrane. The Reverse osmosis (RO) membrane pore size is very small allowing only small amounts of very low molecular weight solutes to pass through the membranes. It is a concentration process using a $100 \mathrm{MWCO}$ (molecular weight cutoff), $700 \mathrm{psig}$, temperature lower than $40^{\circ} \mathrm{C}$ with cellulose acetate membranes and $70-80^{\circ} \mathrm{C}$ with composite membranes. MWCO is the equivalent molecular weight of the smallest protein that would exhibit above $90 \%$ rejection. Diafiltration (DF) is a specialized type of ultrafiltration process in which the retentate is diluted with water and reultrafiltered, to reduce the concentration of soluble permeate components and to further increase the concentration of retained components. 


\section{USE OF MEMBRANE IN DAIRY INDUSTRY}

In the modern dairy processing, membranes play a major role in clarification of the milk, increase the concentration of the selected components as well as separation of the specific valuable components from milk or dairy by- products etc. Membrane separation technology seems a logical choice for the fractionation of milk, because many milk components can be separated on size (Figure 2) (Brans et al., 2004). Membranes are already well established in the processing of whey and are gaining popularity in other dairy applications (Daufin et al., 2001). The membrane technology improves the economics of dairy by reducing the cost of production as well generating new revenue resources (Siebert et al., 2001). Membrane technology proves a suitable and economical alternative to many important processing stage of milk in dairy industry such as centrifugation, bactofugation, evaporation, demineralization of whey, etc (Pouliot, 2008). The $\mathrm{CO}_{2-}$ aided cold MF process has the potential to become economically attractive to the dairy industry, with direct benefits for the quality and shelf life of dairy products (Fristch and Moraru, 2008). Initial reports have indicated that MF will reject fat and microbes while allowing other milk constituents to pass through the membrane, resulting in (theoretically) fat-free, bacteria-free milk (Piot et al., 1987). The membrane area of RO has stabilized around $60,000 \mathrm{~m}^{2}$, mainly for whey concentration. $\mathrm{MF}$ is developing due to its capability to retain, partly or totally, particles (microorganisms, casein micelles, fat globules), and NF has a large field of applications due to its intermediate selectivity (200 to 1,000 Da) between UF and RO (demineralization, de-ionization, purification) in

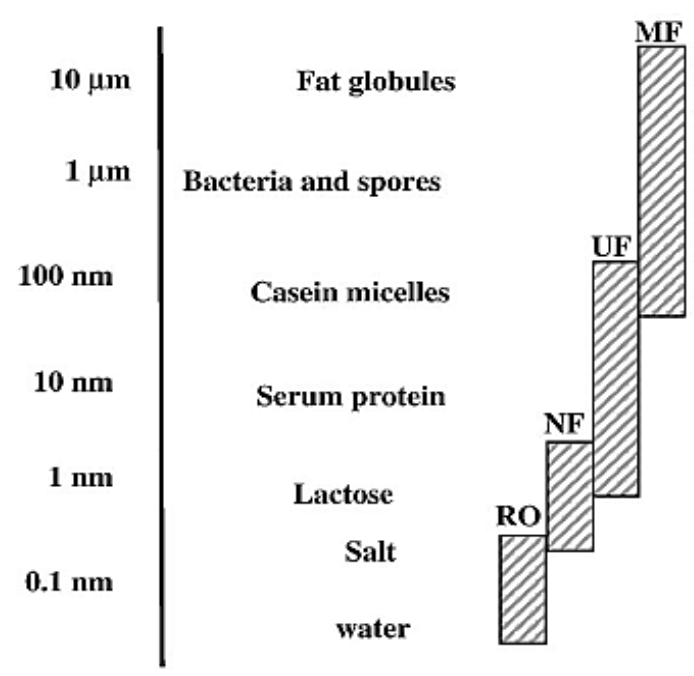

Figure 2. Components in milk: size indication and membrane processes. $\mathrm{MF}=$ Microfiltration, $\mathrm{UF}=$ Ultrafiltration, $\mathrm{NF}=$ Nanofiltration, RO = Reverse osmosis (Adopted from: Daufin et al., 2001).

particular for whey protein valorization (Saxena et al., 2009).

\section{APPLICATION OF MEMBRANES IN DIFFERENT FIELDS OF DAIRY TECHNOLOGY}

Various types of membrane filters with different properties are available in market (Table 1) and commonly used in the dairy industry. Membranes have been applied in different fields of dairy technology including shelf life of milk, whey processing, cheese industry, milk protein processing, fractionation of milk fat and desalting or demineralization.

Table 1. Commonly used membrane techniques in dairy industry

\begin{tabular}{|c|c|c|c|c|c|}
\hline Type & Pore size & $\begin{array}{c}\text { Molecular } \\
\text { weight cut off }\end{array}$ & Pressure and principle & Compounds in retentate & $\begin{array}{l}\text { Application in dairy } \\
\text { industry }\end{array}$ \\
\hline Microfiltration & $0.2-2 \mu \mathrm{m}$ & $>200 \mathrm{kDa}$ & $\begin{array}{l}\text { Low pressure (below } 2 \\
\text { bar) driven membrane } \\
\text { process }\end{array}$ & $\begin{array}{l}\text { Low retentate, separation } \\
\text { of protein, bacteria and } \\
\text { other particulates }\end{array}$ & $\begin{array}{l}\text { - Skim milk and cheese } \\
\text { - Dextrose clarification } \\
\text { - Bacteria removal }\end{array}$ \\
\hline Ultrafiltration & $1-500 \mu \mathrm{m}$ & $1-200 \mathrm{kDa}$ & $\begin{array}{l}\text { Medium pressure }(1-10 \\
\text { bar) pressure driven } \\
\text { process to overcome the } \\
\text { viscosity }\end{array}$ & $\begin{array}{l}\text { Large retentate with } \\
\text { casein micelles, fat } \\
\text { globules, colloidal } \\
\text { minerals, bacteria and } \\
\text { somatic cells }\end{array}$ & $\begin{array}{l}\text { - Standardization of milk, } \\
\text { reduction of calcium and } \\
\text { lactose } \\
\text { - Protein, whey, milk } \\
\text { concentration }\end{array}$ \\
\hline Nanofiltration & $0.5-2 \mathrm{~nm}$ & 300-1,000 Da & $\begin{array}{l}\text { Medium to high pressure } \\
\text { (5-40 bar), mass transfer } \\
\text { phenomena by size } \\
\text { exclusion and } \\
\text { electrostatic interactions }\end{array}$ & $\begin{array}{l}\text { Low productivity, } \\
\text { separate monovalents } \\
\text { salt and water }\end{array}$ & $\begin{array}{l}\text { Desalting of whey, lactose } \\
\text { free milk, volume } \\
\text { reduction }\end{array}$ \\
\hline $\begin{array}{l}\text { Reverse osmosis } \\
\text { or hyperfiltration }\end{array}$ & No pores & $100 \mathrm{Da}$ & High pressure, 10-100 bar & $\begin{array}{l}\text { Based on the principle of } \\
\text { solubility, low } \\
\text { productivity }\end{array}$ & $\begin{array}{c}\text { volume reduction, recovery } \\
\text { of total solids and water }\end{array}$ \\
\hline
\end{tabular}




\section{Application of membranes in extending shelf life of milk}

Extended shelf life (ESL) milk products are products that have been treated in a manner to reduce the microbial count beyond normal pasteurization, packaged under extreme hygienic conditions, and have a prolonged shelf life under refrigerated conditions (Rysstad and Kolstad, 2006). Microfiltration constitutes an alternative to heat treatment to reduce the presence of bacteria and improve the microbiological safety of dairy products while preserving the taste (Pafylias et al., 1996). It is a non thermal method of removing bacteria and spores from milk, whey and cheese brine and extending shelf life without damaging sensory attributes (Meersohn, 1989). The significant reduction of mesophilic, Salmonellae and Listeria count have been reported upon using MF with 1.4 $\mu \mathrm{m}$ pore size (Madec et al., 1992). Cold MF could also minimize microbial fouling of the membrane and prevent the germination of thermophilic spores (Fristch and Moraru, 2008). Fristch and Moraru (2008) performed a study to analyse microbiological, chemical, and somatic cell count to evaluate the effect of MF on the composition of skim milk and found that permeate flux increased drastically when velocity was increased from 5 to $7 \mathrm{~m} / \mathrm{s}$.

By the suitable modifications in the membranes structure, design and composition, it is possible to make milk free from bacteria (Malmberg and Holms, 1988; Olesen and Jensen, 1989). ESL milk has been prepared by removing bacteria from milk by MF without causing any compositional change or negligible decrease in the total protein by 0.02 to $0.03 \%$ (Hoffmann et al., 2006). A thermal treatment or combination of heat treatment and membrane filtration are involved in the production of ESL milk (Lorenzen et al., 2011).

By adding a filtrate circulatory system in the concentrate circulatory system of membrane filters (better known as UTMP concept Uniform Transmembrane Pressure concept), up to $99.70 \%$ of the bacterial load in skim milk has been achieved by Alfa Laval (Olesen and Jensen, 1989). Tetra Alcross Bactocath of Alfa Laval removes the bacteria and spores from milk by separating milk into cream and skim milk and then separates the skim milk from bacteria and spores by microfiltration, while retaining all bacteria and spores in retentate which is about $0.5 \%$ of the original milk volume. The retentate is mixed with suitable amount of cream and mixed in filtered milk after pasteurizing it. As the heat treatment is given to a very small amount of milk, the organoleptic and sensory attributes of milk are retained. It extends the shelf life of milk by 12 to $45 \mathrm{~d}$ at $4^{\circ} \mathrm{C}$ (Olesen and Jensen, 1989; Puhan, 1992; Saboya and Maubois, 2000; Goff and Griffiths, 2006). The major hitch is that it does not remove all pathogenic bacteria from milk, thus still necessitate the heat treatment (Rosenberg, 1995).
The somatic cell counts (SCC) increase in the milk of lactating cows suffering from mastitis and thus severely affecting the composition and quality of milk (Sharma and Maiti, 2010; Sharma et al., 2011; Sharma et al., 2012a; Sharma et al., 2012b). This somatic cell count can be reduced up to $100 \%$ by the application of combined processes of MF (microfiltration) followed by HHT (high heat treatment) (Pedersen, 1992). Damerow (1989) reported the extension of shelf life of refrigerated milk from $12 \mathrm{~d}$ to $18 \mathrm{~d}$ at $8^{\circ} \mathrm{C}$ by the combined application of MF and HHT without compromising sensory attributes by reducing the number of psychrotrops. The MF process is more efficient in removing bacteria and spores than the bactofugation (Stack and Sillen, 1998). With the direct epifluorescent filter technique (DEFT) technology, keeping quality of milk can be judged in short time by concentrating the bacterial cells and their spores as well as somatic cells by membranes followed by quantification of these by epifluorescent microscopy (Pettifer, 1982).

Recently narrow pore sizes in smooth inert silicon nitride surface microsieves have been prepared by micromachining technology to increase the selectivity and permeability to pass liquids at lower transmembrane pressure (Brans et al., 2004). The microsieves also reduce the fouling as well as microbial count significantly in milk (Van Rijn and Kromkamp, 2001).

\section{Application of membranes in whey processing}

Whey is a dairy by-product which is obtained during the preparation of milk products viz. cheese, paneer and casein. Paneer is an Indian dairy product similar to soft cheese prepared by coagulating casein with citric acid, lactic acid or tartaric acid (Kumar et al., 2011a; Kumar et al., 2008). Whey is simply drained in most of the cases in developing countries. This causes huge loss of valuable nutrients as well as creating environmental hazards. The separation or concentration of whey nutrients by traditional method is cumbersome and time consuming. By application of different membrane filtration technology, the nutrients in whey are concentrated, fractionalized or purified into valuable products such as whey protein concentrate/ isolates, $\alpha$-lactalbumin, $\beta$-lactoglobulin, lactose and salts (Figure 3). Up to $60 \%$ more saving on fuel has been reported in whey concentration by applying RO over the traditional evaporation methods. By application of UF and DF, the protein content of the whey protein concentrate can be increased by 35 to $85 \%$ of the total solids whereas by removing bacteria and fat by passing whey through MF, the protein content of whey protein isolates can be increased to 90\% of the total solid content (Lipnizki, 2010).

The membrane separation of bacteria and spores also leads to production of high quality whey protein concentrate (WPC) and whey protein isolates (WPI) with inherent 


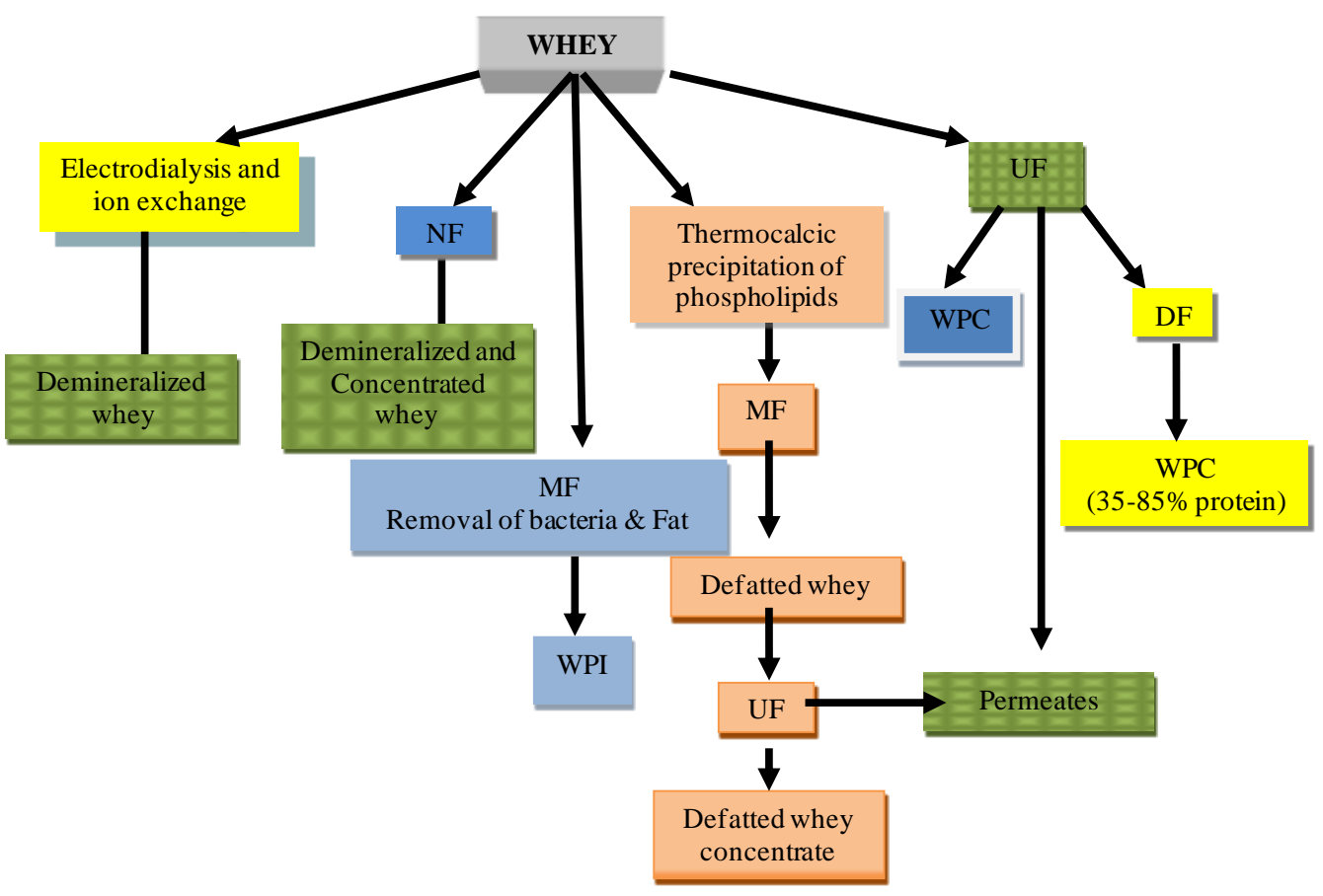

Figure 3. Diagrammatic representation of use of membrane in whey processing.

functional properties from whey (Lipnizki, 2010) as it avoid the denaturation of whey or serum proteins. These whey proteins are used in food industry for their high biological value as well as their ability to improve the functional properties (emulsifying, foaming and gelling) of the food products (Harper, 1992). The removal of as much lipids as possible from whey by efficient membrane function produces whey protein concentrate with good keeping quality (Harper, 1992). At present the WPC are prepared on industrial scales by using UF, however fouling of membranes still remains a concern. UF and RO have application in production of concentrated whey and whey protein concentrates (Sienkiewicz and Riedel, 1990).

The development of off-flavour in these whey products due to the impurities of lipids causing rancidity remain the major concern (Morr and Ha, 1993). A number of studies have suggested the removal of residual fat from whey by thermocalcic precipitation under which phospholipids are aggregated by calcium under heat treatment for $8 \mathrm{~min}$ at $50^{\circ} \mathrm{C}$ followed by removal of the precipitates by $\mathrm{MF}$ and UF (Fauquant et al., 1985; Harper, 1992; Gesan et al., 1995). The advances in MF make it easier to direct removal of lipoproteins by separating the transmembrane pressure from the inlet pressure limiting the fouling.

With the use of membrane technology, it is possible to concentrate and separate whey proteins in their undenatured form with high functional property in native whey as compared to traditional sweet cheese whey (Maubois, 2002). Native whey protein concentrates (NWPC) and native whey protein isolates (NWPI) are produced by UF concentrating the native whey (Maubois et al., 2001), showing excellent gelling, foaming and reconstituability on drying (Ostergaard, 2003). At present, these native whey proteins are utilized extensively in human nutrition as an integral component of weight balancing products (Burton-Freeman, 2008) and in baby foods due to lower risk of hyperthreoninemia due to lack of glycomacropeptides which in turn are rich in threonine (Rigo et al., 2001). The individual whey protein can be concentrated or fractionated by application of membrane technology. This facilitates the production of WPC with the enrichment of specific proteins or with single proteins. The composition of whey proteins differ very little from that of membrane permeates obtained during concentration of the casein (Brans et al., 2004). Doyen et al. (1996) reported that the main concern during the preparation of whey protein concentrate is fouling as membranes with different permeability have the comparable flux due to the pressure independent flux regime. A typical whey micro-filtration process may run in long cycles of about $24 \mathrm{~h}$, which offer great potential for the formation of bacterial biofilms leading to reduced membrane performances.

\section{Application of membranes in Cheese industry}

Membrane filtration technology has number of applications in cheese industry such as improving the nutritive quality, better compositional control and yield of cheese by increasing the total solid content, utilization of whey during preparation of cheese, comparatively reducing the requirement of rennet and starter culture. Concentrating 
the milk prior to cheese making opens a new arena in cheese industry thereby reducing the cost as well as hasten the whole procedure of cheese making (Henning et al., 2006). The quality of cheese brine is maintained easily by membrane filters of pore size of $100 \mu \mathrm{m}$ to removing bacteria and spores as well as other extraneous matters and maintaining the chemical balance of brine which results in production of high quality cheese with superior flavour and shelf life (Ottosen and Konigsfeldt, 1989).

The UF and MF are most commonly used in the cheese industry.

Use of UF in cheese making: UF technology in cheese processing is highly remunerative by concentrating milk by a factor of 1.2 to 2.0 times (Rosenberg, 1995) and increase in the casein: protein ratio (Guinee et al., 1995; Guinee et al., 2006; Johnson and Lucey, 2006) leading to fewer requirements of processing equipments, better compositional and quality control as well as improving the yield of cheese. A 13 to $14 \%$ saving of skim milk has been reported during preparation of quarg cheese with the application of UF process as compared with traditional process (Pedersen and Ottosen, 1992). By removing the water during concentration of milk by the application of membrane filtration technology, it is possible to make cheese without whey, thus do not require the use of cheese vat and avoid cumbersome processing steps of removal and draining of whey. However, some workers reported the negative impact on the ripening of semi-hard and hard cheese due to increased whey content in cheese prepared by concentrated milk (Qvist, 1987). Lipnizki (2010) rightly called UF as complementary process of cheese making. With the application of UF, good quality fresh and brine cheese is obtained with higher yield (Pedersen and Ottosen, 1992; Puhan, 1992; Mistry and Maubois, 1993). Maubois et al. (1969) first patented the procedure of production of cheese on industrial basis from UF retentate by using MMV method (a process named after its inventors Maubois, Mocquot and Vassal) by concentrating the milk by 5 to 7 times and getting the high quality curd. The increase in the viscosity and buffering capacity of such cheese milk needs certain procedural modifications in the process of cheese making (Pouliot, 2008). UF of milk is done to save cost during preparation of semi-hard and hard cheese by increasing the salt and whey protein concentration but it causes compromised sensory and functional properties (Mistry and Maubois, 1993) with slower ripening rate due to decreased proteolysis caused by reduction chymosin and rennin action and presence of more whey proteins (Neocleous et al., 2002). Some reports mentioned that UF have not given good results in making of fresh cheese from acidified curd as it is difficult to process high acidic milk by these traditional membranes. Increasing the $\mathrm{pH}$ before fermentation results in poor sensory attributes with enhanced proteolysis and mineral contents. With the introduction of advanced ceramic and polysulfone membranes, it is possible to apply UF to acidic milk with $\mathrm{pH} 4.4$ to 4.6 in the production of better quality of fresh cheese (Jelen and Renz-Schauen, 1989).

Based on the concentration factors and increase in the protein content, there are three different types of retentate obtained in the UF viz. low concentrated retentate (LCR), medium or intermediate concentrated retentate (MCR) and liquid pre-cheese (LPC) (Rosenberg, 1995; Henning et al., 2006) (Table 2).

Use of $M F$ in cheese making: The $\mathrm{MF}$ casein concentrated milk is very suitable for various cheese preparations due to its superior microbial quality achieved after removing bacteria and spores from milk, as well as optimization of the different major milk components. The MF pre-treatment of cheese milk improves the firmness of curd, accelerate ripening (Pierre et al., 1992; Caron et al., 1997; Maubois, 2002), reduce the amount of additives e.g. $\mathrm{CaCl}_{2}$ (Schafroth et al., 2005) and facilitates heating at higher temperature. Further the UHT milk need higher amount of rennet for coagulation. By application of UF, UHT milk is coagulated with lesser amount of rennet by compensating the hindrance to coagulation arising from the formation of complexes between k-casein and $\beta$-lactoglobulin by reduction of the zeta potential of the casein micelle (Mistry and Maubois, 1993).

The MF has future possibilities in standardization of protein in cheese milk and fortification with casein micelle

Table 2. Role of UF in concentrating cheese milk

\begin{tabular}{|c|c|c|c|}
\hline Retentate & $\begin{array}{l}\text { Concentration } \\
\text { factor }\end{array}$ & Types of cheese & Remark \\
\hline $\begin{array}{l}\text { Low concentrated retentate } \\
\text { (LCR) }\end{array}$ & 1.2-2: 1 & $\begin{array}{l}\text { Cheddar, brick, cottage cheese, } \\
\text { colby, mozarella, edam, saint } \\
\text { paulin, quag }\end{array}$ & $\begin{array}{l}\text { 4.5-5\% more protein in cheese, Increase } \\
\text { yield, efficient utilization of cheese vat, } \\
\text { good compositional control }\end{array}$ \\
\hline $\begin{array}{l}\text { Medium/concentrated retentate } \\
\text { (MCR) }\end{array}$ & 2-6: 1 & $\begin{array}{l}\text { Cheddar, feta, havarti, gouda, and } \\
\text { blue cheese }\end{array}$ & $\begin{array}{l}\text { 6-8\% more yield, need special cheese } \\
\text { making equipment }\end{array}$ \\
\hline Liquid pre cheese (LPC) & $\begin{array}{l}\text { Same as of } \\
\text { cheese curd }\end{array}$ & $\begin{array}{l}\text { Feta, mozzarella, quarg, camembert, } \\
\text { ricotta, cream cheese, mascarpone } \\
\text { and saint mauri }\end{array}$ & $\begin{array}{l}\text { Very economical, cheese vat not required, } \\
\text { minimum whey drainage }\end{array}$ \\
\hline
\end{tabular}

Source: van Leeuwen et al., 1987; Mistry and Maubois 1992; Rosenberg, 1995; Henning et al., 2006. 
powder (Mistry and Maubois, 1993). The MF followed to HTT (high temperature treatment) is more efficient than single stage bactofugation in terms of microbial quality. But this treatment of MF followed by HTT modifies rennet coagulation and increases the water holding capacity, necessitating adjustments in the parameters during cheese preparation (Pedersen and Ottosen, 1992).

\section{Application of membranes in milk protein processing}

Milk proteins especially caseins play important role in white turbid appearance and viscosity of milk. By application of ultra filtration, the level of protein content in milk is adjusted without adding any extraneous protein source by removing the water. This causes the maintenance of the composition, nutritive value, physico-chemical properties and sensory attributes of the milk irrespective to the variation caused by the genetic as well as environmental factors (Puhan, 1992). Adding of 1\% ultra filtered protein enriched milk in skim milk has improved the viscosity and sensory attributes to similar to full cream milk (Quinones et al., 1997). The milk protein concentrate (MPC) containing 50 to $58 \%$ proteins of good functionality are prepared by application of MF, UF and diafiltration (DF) technologies either alone or in combinations.

Fractionalization of milk protein: Separating out the various milk components of different sizes from milk by applying membrane technology (Figure 3) will transform dairy industry into very efficient and profitable enterprises. Jimenez-Lopez et al. (2008) described membrane pore size homogeneity, concentration polarization phenomena and membranes fouling as main factors determining the fractionalization of milk components. The milk protein concentrates (with 50 to $85 \%$ protein in the products) and milk concentrates (with more than $85 \%$ protein in the products) are increasingly prepared by using MF (Novak, 1992). The composition, heat stability, rheological and textural properties of these products depend upon the type of membranes used and prevailing processing conditions such as, temperature, $\mathrm{pH}$, time of processing. The judicious use of these factors should be selected based on the ultimate use of the MPC (milk protein concentrate) and MP (milk protein) (Novak, 1992; Hallstrom and Dejmek, 1988). Novak (1992) suggested UF processing at 50 to $60^{\circ} \mathrm{C}$ with high flow rate to minimize the whey protein denaturation for desired rheological properties.

A lot of work has performed to recover valuable proteinacious components from dairy waste streams (Chakravorty and Singh, 1990). Dairy proteins are valuable products and used as high-value food additives, neutriceutical and therapeutics. The milk protein can be recovered by using MF, UF and NF processes. MF of milk separates the casein micelles and whey proteins (Maubois et al., 1987). The various milk proteins such a casein and serum or whey proteins are separated in a simple and economic method by applying membrane filters of $0.2 \mu \mathrm{m}$ pore size at constant TMP, without the need of application of heat and chemicals.

Casein: Membrane technology has revolutionized the casein industry. Application of different membrane types with desired pore size either alone or in combination with enzymatic action, chromatography lead to the concentration, fractionalization and purification of milk proteins. The physico-chemical properties of casein in relation to membranes largely depend upon the ionic strength as well as temperature (Mulvihill, 1992). At suitable ionic strength, it is possible to concentrate and fractionate casein as $\beta$-casein at $5^{\circ} \mathrm{C}$, skim milk at $4^{\circ} \mathrm{C}$ and $\mathrm{pH} 4.2$ to 4.6 (Famelart et al., 1989) using MF and UF separating $\beta$-casein in permeates and $\alpha$ and $\kappa$-casein in retentate (Murphy and Fox, 1990). The native casein can be concentrated in retentate by passing the skim milk into $\mathrm{MF}$ with $0.2 \mu \mathrm{m}$ pore size (Fauquant et al., 1985; Maubois and Ollivier, 1992). Upto $90 \%$ casein concentration is possible by DF and it can be used for industrial, pharmaceutical as well as edible purposes (Maubois and Ollivier, 1992). The concentrated casein and native casein micelles can be prepared through ceramic, ceraflow, membralox membrane with different flux (Pouliot et al., 1996; Vadi and Rizvi, 2001; Van Rijn and Kromkamp, 2001; Brans et al., 2004). The significant improvement was recorded in flux with 65 $\mathrm{kPa}$ transmembrane pressure having flow velocity of 12.5 metre/second (Krstic et al., 2002).

Papadatos et al. (2003) found that although there was higher profit in the production of cheddar and mozzarella cheese by MF milk in North America but the profit changed little with the increase in concentration of casein from 2 to 3 times. The fouling is major concern than selectivity during the concentration of casein in milk as some whey proteins are there in casein and vice versa and thus affecting the yield of cheese as well as whey concentrates (Brans et al., 2004). Use of membrane process accompanied with other advance technology as liquid chromatography, leads to purification of casein derived bioactive peptides showing morphine-mimicking, cardiovascular and immunostimulating activities (Maubois and Ollivier, 1992; Mulvihill, 1992).

Fractionalization of whey protein: Whey proteins are obtained by concentrating and purification from whey. Govindasamy-Lucey et al. (2007) and Lawrence et al. (2008) separated the whey protein from skimmed milk by polymeric microfiltration in permeate flux. Mass flux form of permeated whey protein with permeates flux, mainly determine the whey protein concentration and fractionalization (Gauthier et al., 2006). With the advancement of newer technology in membrane process, it is possible to recover growth factor from whey (Gauthier et al., 2006). Attempts have been made to tap the growing 
market of health foods by separating immunoglobulins and growth factors from colostrum by applying MF and UF with suitable modifications (Regester et al., 2003; Piot et al., 2004).

The $\beta$-lactoglobulin is separated by the membrane process followed by heat treatment (Maubois et al., 1987; Pearce, 1987). The $\beta$ lactoglobulin can be fractionized from defatted whey proteins by using MF and centrifugation followed by purification by UF with electrodialysis (ED) or DF. $\beta$-lactoglobulin is purified by diafiltration of supernatant (Maubois et al., 1987), while immunoglobulins are separated from whey protein concentrates by using membrane technology (Scott and Lucas, 1989). The $\alpha$-lactalbumin is separated and purified by applying UF on solubilised MF retentate at neutral pH (Rosenberg, 1995). With the introduction of inorganic membranes with polyvinylimidazole derivates, the pure $\alpha$-lactalbumin can be obtained in filtrate but the fouling proves major constraint (Chaufer et al., 1991; Chen and Wang, 1991). The whey proteins can be separated from WPI by applying UF/DF with more than $99 \%$ purity (Mailliart and Ribadeau-Dumas, 1988). The use of hydrophilic cellulose membrane made it possible to separate low molecular weight compounds from high molecular weight compounds (Mehara and Donnely, 1993). Lactoferrin and lactoperoxidase are recovered from defatted WPC on industrial scale by using ion-exchange chromatography (Perraudin, 1991).

\section{Application of membranes in milk fat processing}

Traditionally, cream is separated from whole milk by energy intensive centrifugation in which lighter fat globules moves towards the centre and heavier skim milk move towards periphery under the centrifugal force. The cream separation is also possible by energy saving membranes technology producing skim milk with good storage quality and improved sensory attributes of cream without causing any damage to fat globular membranes. Goudedranche et al. (2000) reported the fractionation of fat globules by application of membranes of $2 \mu \mathrm{m}$ size. The size of fat globules have profound impact on textural and sensory attributes as the cream with smaller fat globules have fine texture and improved flavour than cream with large fat globules.

\section{Role of membranes in desalting or demineralization}

The removal of minerals from whey increases its value (Kelly et al., 1991). The cheese whey is rich in salt and acids and the reduction or demineralization of whey is essential before its use and to alleviate the environmental hazards. The demineralization is done by electrodialysis and ion exchange process (Greiter et al., 2002) in the dairy industry to get up to $60 \%$ reduction of minerals (Kelly et al., 1991). The efficiency of electrodialysis can be increased by pre-concentrating up to $20 \%$ dry matter by RO or evaporation. By ion exchange, desalting of whey is done by passing it over ion exchange column and the rate of removal of ions depends upon the resin used in the column as well as the type of ions. The need of lots of water and chemicals for regeneration of resins is the major limitations of this technology.

The NF membranes with molecular weight cutoff (MWCO) ranging between 200 to 1,000 Daltons are best suited for demineralization of whey as these membranes are permeable to salt and monovalent ions but impermeable to organic compounds. The carboxyl group of organic compounds bound to these membranes under prevailing acidic conditions. This technology simultaneously demineralises whey at the time of concentrating, helping in savings in term of cost, time and water disposal (Kelly et al., 1991). The NF is more economical than electrodialysis and a method of choice for partial desalting of whey. NF membranes are highly permeable to water and monovalent ions. The mineral contents of the whey is reduced by $35 \%$ and ash content by 3 to 4 times in addition to increase concentration of whey by applying nanofiltration (NF), making it suitable for the people having cardiovascular diseases. The mineral content of whey is further reduced by $45 \%$ by applying DF (Kelly et al., 1991; Lipnizki, 2010). The reduction of mineral content in whey, liquor and brines on industrial scale can be done mainly by NF (Kelly et al., 1991; Van der Horst et al., 1995; Horton, 1997a; b; Horton, 1998). Daifiltration also causes the removal of ions to a greater extent.

\section{Other applications}

The use of different membranes accompanied with suitable heat treatments leads to the development of several dairy products with unique characteristics as better compositional control, binding, texture, juiciness, etc. With the help of membrane technology, several novel products are introduced in market as lactose free milk for lactose intolerant people, low calcium milk, non fat yoghurt, high protein low lactose ice cream, protein fortified low fat milk, whey based beverages, etc. By applying RO (reverse osmosis), milk is condensed by removing about $70 \%$ of its water and retaining all other components of milk without undergoing any thermal processing. During preparation of fermented dairy milk such as cheese, yoghurt and curd, the protein and total solids of standardized UF milk show better textural and nutritional properties than those of prepared by either adding milk powder or evaporated milk (Puhan, 1992). It is easier to control the textural and compositional properties of milk by membrane filtration technology, but it necessitates better attention to the selection of starter and incubation/ ripening conditions such as temperature, time and pH (Rosenberg, 1995: Lipnizki, 2010). Rosenberg 
(1995) noted that such changes is due to the increasing content of lactose and minerals, higher osmotic pressure, change in the $\mathrm{pH}$, change in ionic strength as well accumulation of some inhibitory compounds in the UF treated milk.

The transport cost of milk is reduced by membrane technology by pre- concentrating it, removing the water and lactose or dewatering it at farm level and thus decreasing the volume of transported milk without damaging its sensory attributes (Rattray and Jelen, 1996). RO of milk results in permeate containing protein and minerals whereas UF of milk produces permeate consisting of water and lactose. Membrane technology is used to separate $\kappa$-caseinglycomacropeptide (GMP), which have pharmaceutical uses in controlling the adhesion of $E$. coli cells to the intestine walls, protects against influenza and prevents adhesion of tartar to teeth (Maubois and Ollivier, 1992).

\section{FOULING OF MEMBRANES}

Membranes are having some limitations such as fouling of membranes due to blockage of membrane pores, adsorption of particles on the pores, deposition of protein and minerals, cake formation and depth fouling (James and Chen, 2003; Popovic et al., 2010; Anand et al., 2012), and bacterial biofilms (Kumar and Anand, 1998; Tang et al., 2009). The fouling is caused by the accumulation of particles, bacteria and sediments present in milk leading to remarkable loss in the efficiency of membranes. The fouling of membrane remains the major concern in dairy industry (Gesan et al., 1995; Makardij et al., 1999). The fouling of membranes is mainly affected by several factors such as backpulsing, crossflushing, backwashing, particle size, membrane surface chemistry and ionic strength (Huimin et al., 2001).

This major issue of fouling in membranes can be trounced by regular cleaning of membranes at appropriate time intervals, use of low fouling membranes, membrane modules with suitable channel heights, by applying high pressure, application of electric potential, ultrasound waves, microturbulence, ceramic membranes, uniform transmembrane pressure (UTP), vibrating and rotating disc modules, use of turbulent flow of liquids (Vishwanathan and Ben, 1989; Saboya and Maubois, 2000; Duriyabunleng et al., 2001; Ding et al., 2002; Wakeman and Williams, 2002) and high frequency back pulsing (Levesley and Hoare, 1999).

\section{FUTURE TRENDS}

There is need for progressive development of innovative applications based on the technique. Currently, the membranes for dairy processes have rather a low capacity owing to strong flux decline by fouling and processes are energy demanding because of the high cross-flow velocity that is required to control fouling. Furthermore, methods to control fouling have increased the complexity in equipments and operation. Besides fouling, selectivity is an important issue for membrane fractionation of milk. Therefore, we need innovative techniques for the development of cheap, easily available, superior and long lasting membranes. Consumers are looking for products with increased freshness and higher quality and the retailers require products with extended shelf life and the demands of both can be fulfilled by the use of the membrane technology.

\section{CONCLUSION}

Introduction of membrane technology into dairy science witnesses phenomena of mutual benefit for membranes as well as for dairy industry. The marked improvement in the nutritive quality and sensory attributes of the existing dairy products with higher yields in addition to development of several innovative dairy products became possible by the application of membrane technology. Continuing the efforts for the development of superior membranes will further expand the role of membranes in dairy processing.

\section{ACKNOWLEDGEMENTS}

This work was supported by the research grant from the Chungbong Academic Research Fund of Jeju National University, Jeju, Korea in 2010.

\section{REFERENCES}

Anand, A., A. Hassan, and M. Avadhanula. 2012. The effects of biofilms formed on whey reverse osmosis membranes on the microbial quality of the concentrated product. Int. J. Dairy Technol. 65:451-455.

Balannec, B., M. Vourch, M. Rabiller-Baudry, and B. Chaufer. 2005. Comparative study of different nanofiltration and reverse osmosis membranes for dairy effluent treatment by dead-end filtration. Sep. Purif. Technol. 42:195-200.

Brans, G., C. G. P. H. Schroen, R. G. M. Van der Sman, and R. M. Boom. 2004. Membrane fractionation of milk: state of the art and challenges. J. Memb. Sci. 243:263-272.

Burton-Freeman, B. M. 2008. Glycomacropeptide (GMP) is not critical to whey-induced satiety, but may have a unique role in energy intake regulation through cholecystokinin (CCK). Physiol. Behav. 93:379-387.

Caron, A., D. Saint Gelais, and Y. Pouliot. 1997. Coagulation of milk enriched with ultrafiltered or diafiltered microfiltered milk retentate powders. Int. Dairy J. 7:445-451.

Chakravorty, B. and D. P. Singh. 1990. Concentration and purification of gelatin liquor by ultrafiltration. Desalination. 78:279-286.

Chaufer, B., M. Rollin, and B. Sebille. 1991. High-performance 
liquid chromatography and ultraPltration of whey proteins with inorganic porous materials coated with polyvinylimidazole derivatives. J. Chromatogr. 548:215-228.

Chen, J. P. and C. H. Wang. 1991. Microfiltration affinity purification of lactoferrin and immunoglobulin $\mathrm{G}$ from cheese whey. J. Food Sci. 56:701-706.

Childress, A. E. and M. Elimelech. 2000. Relating nanofiltration membrane performance to membrane charge (Electrokinetic) characteristics. Environ. Sci. Technol. 34:3710-3716.

Damerow, G. 1989. Die anwendung der mikrofiltration fur die konsummilch, kessel-milch, Molke. Dtsch. Molkerei Zeitung. 110:1602-1608

Daufin, G., J. P. Escudier, H. Carrere, S. Berot, L. Fillaudeau, and M. Decloux. 2001. Recent and emerging applications of membrane processes in the food and dairy industry. Trans. ICheme. 79:89-102.

Ding, L., O. Al-Akoum, A. Abraham, and M. Y. Jaffrin. 2002. Milk protein concentration by ultrafiltration with rotating disk modules. Desalination 144:307-311.

Doyen, W., W. Adriansens, B. Molenberghs, and R. Leysen. 1996. A comparison between polysulfone, zirconia and organomineral membranes for use in ultrafiltration. J. Memb. Sci. 113: $247-258$

Duriyabunleng, H., J. Petmunee, and C. Muangnapoh. 2001. Effects of the ultrasonic waves on microfiltration in plate and frame module. J. Chem. Eng. Jpn. 34:985-989.

Famelart, M. H., C. Hardy, and G. Brule. 1989. Optimisation of the preparation of p-casein-enriched solution. Lait 69:47-57.

Fauquant, J., E. Vieco, G. Brule, and J. L. Maubois. 1985 Clarification of sweet cheese whey by thermocalcic aggregation of residual fat. Lai. 65:1-20.

Fauquant, J., J. L. Maubois, and A. Pierre. 1988. Microfiltration du lait sur membrane minérale. Tech. Laitiere Mark. 1028:21-23.

Fritsch, J. and C. I. Moraru. 2008. Development and optimization of a carbon dioxide-aided cold microfiltration process for the physical removal of microorganisms and somatic cells from skim milk. J. Dairy Sci. 91:3744-3760.

Gauthier, S. F., Y. Pouliot, and J. L. Maubois. 2006. Growth factors from bovine milk and colostrum: composition, extraction and biological activities. Lait 86:99-125.

Gesan, G., G. Daufin, U. Merin, J. P. Labbe, and A. Quemerais 1995. Microfiltration performance: Physiochemical aspects of whey pre-treatment. J. Dairy Res. 62:269-279.

Goff, H. D. and M. W. Griffiths. 2006. Major advances in fresh milk and milk products: Fluid milk products and dairy desserts. J. Dairy Sci. 89:1163-1173.

Goudedranche, H., J. J. Fauquant, and J. L. Maubois. 2000. Fractionation of globular milk fat by membrane microfiltration. Lait 80:93-98.

Govindasamy-Lucey, S., J. J. Jaeggi, M. E. Johnson, T. Wang, and J. A. Lucey. 2007. Use of cold microfiltration retentates produced with polymeric membranes for standardization of milks for manufacture of pizza cheese. J. Dairy Sci. 90:45524568.

Greiter, M., S. Novalin, M. Wendland, K. D. Kulbe, and J. Fischer. 2002. Desalination of whey by electrodialysis and ion exchange resins: analysis of both processes with regard to sustainability by calculating their cumulative energy demand. J. Memb. Sci. 210:91-102.
Guinee, T. P., B. T. Kennedy, and P. M. Kelly. 2006. Effect of milk protein standardization using different methods on the composition and yields of cheddar cheese. J. Dairy Sci. 89: 468-482.

Guinee, T. P., P. D. Pudja, W. J. Reville, D. Harrington, O. E. Mulholland, M. Cotter, and T. M. Cogan. 1995. Composition, microstructure and maturation of semi-hard cheese from high protein ultrafiltered milk retentates with different levels of denatured whey protein. Int. Dairy J. 5:543-568.

Hallstrom, M. and P. Dejmek. 1988. Rheological properties of ultrafiltered skim milk. I. Effects of $\mathrm{pH}$, temperature and heat pretreatment. Milchwissenschaft 43:31-34.

Harper, W. J. 1992. New applications of membrane processes- In IDF Spl. Iss. 9201. Brussels, Belgium. pp. 77-108.

Henning, D. R., R. J. Baer, A. N. Hassan, and R. Dave. 2006. Major advances in concentrated and dry milk products, cheese and milk fat-based concepts. J. Dairy Sci. 89:1179-1188.

Hoffmann, W., C. Kiesner, I. Clawinradecker, D. Martin, K. Einhoff, P. C. Lorenzen, H. Meisel, P. Hammer, G. Suhren, and P. Teufel. 2006. Processing of extended shelf life milk using microfiltration. Int. J. Dairy Technol. 59:229-235.

Horton, B. S. 1997a. Whatever happened to the ultrafiltration of milk? Aust. J. Dairy Technol. 52:47-49.

Horton, B. S. 1997b. Water, chemical and brine recycle or reuseApplying membrane processes. Aust. J. Dairy Technol. 52:6870.

Horton, B. S. 1998. The whey processing industry-into the $21 \mathrm{st}$ century. In: Whey. IDF Bulletin. 9804. Brussels, Belgium pp. 12-25.

Huimin, M., L. F. Hakim, C. N. Bowman, and R. H. Davis. 2001. Factors affecting membrane fouling reduction by surface modification and backpulsing. J. Memb. Sci. 189:255-270.

James B. J. and Y. X. D. Jing Chen. 2003. Membrane fouling during filtration of milk-a microstructural study. J. Food Eng. 60:431-437.

Jelen, P. and A. Renz-Schauen. 1989. Quarg manufacturing innovations and their effects on quality, nutritive value, and consumer acceptance. Food Technol. 43:74-81.

Jimenez-Lopez, A. J. E., N. Leconte, O. Dehainault, C. Geneste, L. Fromont, and G. Gesan-Guiziou. 2008. Role of milk constituents on critical conditions and deposit structure in skim milk microfiltration $(0.1 \mu \mathrm{m})$. Sep. Purif. Technol. 61:33-43.

Johnson, M. E. and J. A. Lucey. 2006. Major technological advances and trends in cheese. J. Dairy Sci. 89:1174-1178.

Kelly, P. M., B. S. Horton, and H. Burling. 1991. Partial demineralization of whey by nanofiltration. In: New applications of membrane processes. IDF Bulletin 9201 Brussels, Belgium. pp. 130-140.

Krstic, D. M., M. N. Tekic, M. D. Caric, and D. S. Milanovic. 2002. The effect of turbulence promoter on cross-flow microfiltration of skim milk. J. Memb. Sci. 208:303-314.

Kumar, C. G. and S. K. Anand. 1998. Significance of microbial biofilms in food industry: a review. Int. J. Food Microbiol. 42: 9-27.

Kumar, S. and D. C. Rai. 2010. Effect of antioxidants and paraffin wax on the physico-chemical properties of aerobically packaged buffalo milk paneer at refrigeration temperature. Milchwissenschaft 65:388- 393.

Kumar, S., D. C. Rai, and D. N. Verma. 2008. Effect of different 
levels of lactic acid on the physico-chemical and sensory attributes of buffalo milk paneer. Indian J. Anim. Res. 42:205208.

Kumar, S., D. C. Rai, K. Niranjan, and Z. F. Bhat. 2011a. Paneeran Indian soft cheese variant : a review. J. Food Sci. Technol. Doi 10.1007 s13197-011-0567-x.

Kumar, S., Z. F. Bhat, and P. Kumar. 2011b. Effect of apple pulp and Celosia argentia on the quality of characteristics of Shrikhand. Am. J. Food Technol. 6: 817-826.

Lawrence, N. D., S. E. Kentish, A. J. OConnor, A. R. Barber, and G. W. Stevens. 2008. Microfiltration of skim milk using polymeric membranes for casein concentrate manufacture. Sep. Purif. Technol. 60:237-244.

Levesley, J. A. and M. Hoare. 1999. The effect of high frequency back flushing on the microfiltration of yeast homogenate suspensions for the recovery of soluble proteins. J. Memb. Sci. 158:29-39.

Lipnizki, F. 2010. Cross-flow membrane applications in the food industry. In: Membrane Technology, Vol 3: Membranes for Food Applications (Ed. Klaus-Viktor Peinemann, Suzana Pereira Nunes, and Lidietta Giorno). WILEY-VCH Verlag $\mathrm{GmbH}$ and Co. KGaA, Weinheim.

Lorenzen, P. C., I. C. Decker, K. Einhoff, P. Hammer, R. Hartmann, W. Hoffmann, D. Martin, J. Molkentin, H. G. Walte, and M. Devrese. 2011. A survey of the quality of extended shelf life (ESL) milk in relation to HTST and UHT milk. Int. J. Dairy Technol. 64:166-178.

Madec, M. N., S. Mejean, and J. L. Maubois. 1992. Retention of Listeria and Salmonella cells contaminating skim milk by tangential membrane microfiltration (Bactocatch process). Lait. $72: 327-332$

Mailliart, P. and B. Ribadeau-Dumas. 1988. Preparation of $\beta$ lactoglobulin and p-lactoglobulin-free proteins from whey retentate by $\mathrm{NaCl}$ salting out at low pH. J. Food Sci. 53:743747.

Makardij, A., X. D. Chen, and M. M. Farid. 1999. Microfiltration and ultrafiltration of milk: some aspects of fouling and cleaning. Trans. IChemE. 77:107-113.

Malmberg, R. and S. Holms. 1988. Producing low-bacteria milk by microfiltration. N. Eur. Food Dairy J. 54:30-32.

Maubois, J. L. 2002. Membrane microfiltration: a tool for a new approach in dairy technology. Aust. J. Dairy Technol. 57: 9296.

Maubois, J. L. and G. Ollivier. 1992. New Applications of Membrane Processes. IDF Spl. Iss. 9201. Brussels, Belgium. pp. 15-22.

Maubois, J. L., A. Pierre, J. Fauquant, and M. Piot. 1987. Industrial fractionation of the main whey proteins. IDF Bulletin 212. Brussels, Belgium. Pp. 154-159.

Maubois, J. L., G. Mocquot and L. Vassal. 1969. A method for processing milk and dairy products. French Patent. FR 2 052121.

Maubois, J. L., J. Fauquant, M. H. Famelart, and F. Caussin. 2001. Milk microfiltrate a convenient starting material for fractionation of whey proteins and derivatives. In: Proc. $3^{\text {rd }} \mathrm{Int}$ Whey Conf. The importance of whey and whey components in food and nutrition. München. Germany. pp. 59-72.

Meersohn, M. 1989. Nitrate-free cheese making with the Bactocatch. North Eur. Food Dairy J. 55:108-113.
Mehara, R. K. and W. J. Donnely. 1993. Fractionation of whey protein components through a large pore size, hydrophilic, cellulosic membrane. J. Dairy Res. 60:89-97.

Mistry, V. V. and J. L. Maubois. 1993. Application of membrane separation technology to cheese production. In: Cheese: Chemistry, Physics and Microbiology (Ed. P. F. Fox). Chapman \& Hall: London, 493-522.

Morr, C. V. and E. Y. W. Ha. 1993. Whey protein concentratesand isolates: processing and functional properties. Crit. Rev. Food Sci. Nutr. 33: 431- 476

Mulvihill, D. M. 1992. Production, functional properties and utilization of milk protein products. In: Advanced Dairy Chemistry Volume I. (Ed. P. F. Fox). Chapman and Hall. 369404

Murphy, J. M. and P. F. Fox. 1990. Fractionation of sodium caseinate by ultrafiltration. Food Chem. 39:27-38.

Neocleous, M., D. M. Barbano, and M. A. Rudan. 2002. Impact of low concentration factor microfiltration on the composition and aging of Cheddar cheese. J. Dairy Sci. 85:2425-2437.

Novak, A. 1992. New applications of membrane processes. IDF Spl Iss 9201 Brussels, Belgium. pp. 51-66.

Olesen, N. and F. Jensen. 1989. Microfiltration. The influence of operating parameters on the process. Milchwissenschaft 44: 476-479.

Ostergaard, B. 2003. Adding value to whey by Pro-Frac. Eur. Dairy Mag. 8:20-22.

Ottosen, N. and P. Konigsfeldt. 1999. Microfiltration of cheese brine. Preliminary, APV Nordic, Membrane Filtration, Silkeborg. Denmark.

Pafylias, I., M. Cheryan, M. A. Mehaiab, and N. Saglam. 1996. Microfiltration of milk with ceramic membranes. Food Res. Intl. 29:141-146.

Papadatos, A., M. Neocleous, A. M. Berger, and D. M. Barbano. 2003. Economic feasibility evaluation of microfiltration of milk prior to cheesemaking. J. Dairy Sci. 86:1564-1577.

Pearce, R. J. 1987. Fractionation of whey proteins. Aust. J. Dairy Technol. 42:75-78.

Pedersen, P. J. 1992. New applications of membrane processes. IDF Spl Iss-9201, Brussels, Belgium.pp. 33-50.

Pedersen, P. J. and N. Ottosen. 1992. New Applications of Membrane Processes. IDF Spl Iss 9201. Brussels, Belgium. pp. 67-76.

Perraudin, J. P. 1991. Biologically active proteins. Recently acquired knowledge and separation technology. Lait 71:191211.

Pettipher, G. L. 1982. Developments in assessing milk quality Use of membrane filtration for assessing the hygienic quality of milk and milk products. Int. J. Dairy Technol. 35:59-63.

Pierre, A., J. Fauquant, Y. Le Graet, M. Piot, and J. L. Maubois. 1992. Préparation de phosphocaseinate natif par microfiltration sur membrane. Lait 72:461-474.

Piot, M., J. C. Vachot, M. Veaux, J. L. Maubois, and G. E. Brinkman. 1987. Encremage et epuration bacteri-enne du lait entier cru par microfiltration sur membrane en flux tangentiel. Tech. Laitiere Marketing. 1016:42-46.

Piot, M., J. Fauquant, M. N. Madec, and J. L. Maubois. 2004. Preparation of serocolostrum by membrane microfiltration. Lait 84:333-341.

Piry, A., W. Kühn, T. Grein, A. Tolkach, S. Ripperger, and U. 
Kulozik. 2008. Length dependency of flux and protein permeation in crossflow microfiltration of skimmed milk. J. Memb. Sci. 325:887-894.

Popovic, S., M. Djuric, S. Milanovic, M. N. Tekic, and N. Lukic. 2010. Application of an ultrasound field in chemical cleaning of ceramic tubular membrane fouled with whey proteins. J. Food Eng. 101:296-302.

Pouliot, M., Y. Pouliot, and M. Britten. 1996. On the conventional cross-flow microfiltration of skim milk for the production of native phosphocaseinate. Int. Dairy J. 6:105-111.

Pouliot, Y. 2008. Membrane processes in dairy technology-From a simple idea to worldwide panacea. Int. Dairy J. 18:735-740.

Puhan, Z. 1992. New applications of membrane processes. IDF Spl Iss 9201 Brussels, Belgium. pp. 23-32.

Quinones, H. J., D. M. Barbano, and L. G. Phillips. 1997. Influence of protein standardization by ultrafiltration on the viscosity, colour, and sensory properties of skim and $1 \%$ milk. J. Dairy Sci. 80:3142-3151.

Qvist, K. B. 1987. Objective and sensory assessment of texture of danbo cheese made from milk concentrated 2-fold using ultrafiltration. 272, Beretning/ Statens Mejerifors $\varnothing \mathrm{g}$, Hillerød, Denmark.

Rattray, W. and P. Jelen. 1996. Freezing point and sensory quality of skim milk as affected by addition of ultrafiltration permeates for protein standardization. Int. Dairy J. 6:569-579.

Regester, G. O., D. A. Belford, R. J. West, and C. Goddard. 2003. Development of minor dairy components as therapeutic agents-Whey growth factor extract, a case study. Aust. J. Dairy Technol. 58:104-106.

Rigo, J., G. Boehm, G. Georgi, J. Jelinek, K. Nyambugabo, G Sawatzki, and F. Studzinski. 2001. An infant formula free of glycomacropeptide prevents hyperthreoninemia in formula-fed preterm infants. J. Pediatr. Gastroenterol. Nutr. 32:127-130.

Rosenberg, M. 1995. Current and future applications of membrane processes in the dairy industry. Trends Food Sci. Technol. 6: 12-19.

Rysstad, R. and J. Kolstad. 2006. Extended shelf life milkadvances in technology. Int. J. Dairy Technol. 59:85-96.

Saboya, L. V. and J. L. Maubois. 2000. Current developments of microfiltration technology in the dairy industry. Lait 80:541553.

Saxena, A., B. P. Tripathi, M. Kumar, and V. K. Shahi. 2009. Membrane-based techniques for the separation and purification of proteins: An overview. Adv. Colloid Interface Sci. 145:1-22.

Schafroth, K., C. Fragnière, and H. P. Bachmann. 2005. Herstellung von Käse aus microfiltrierter. konzentrierter Milch. Deutsche Milchwirtschaft. 56:861-863.

Scott, G. H. and D. O. Lucas. 1989. Immunologically active whey fraction and recovery process. US. Patent $4,834,874$.

Sharma, N. and S. K. Maiti. 2010. Incidence, etiology and antibiogram of sub clinical mastitis in cows in durg, Chhattisgarh. Ind. J. Vet. Res. 19:45-54.
Sharma, N., A. K. Srivastava, G. Bacic, D. K. Jeong, and R. K. Sharma. 2012b. Epidemiology. In: Bovine mastitis. $1^{\text {st }}$ edn. Satish serial publishing house, Delhi, India. pp: 231-312.

Sharma, N., G. J. Rho, Y. H. Hong, T. Y. Kang, H. K. Lee, T. Y. Hur, and D. K. Jeong. 2012a. Bovine mastitis: An Asian Perspective. Asian J. Anim. Vet. Adv. 7:454-476.

Sharma, N., N. K. Singh, and M. S. Bhadwal. 2011. Relationship of Somatic Cell Count and Mastitis: An Overview. Asian-Aust. J. Anim. Sci. 24:429-438.

Shekhar, C. and S. Kumar. 2011. Quality of buffalo milk procured from milk vendors- a case study. Ind. J. Anim. Res. 45:223225 .

Shekhar, C., E. Motina, and S. Kumar. 2010. Microbiological quality of raw milk and its public health significance. J. Dairying Foods Home Sci. 29:15-18

Siebert, J. W., L. Alejandro, and K. Sung-Yong. 2001. The commercial potential of new dairy products from membrane technology. J. Food Distrib. Res. 3:24-33.

Sienkiewicz, T. and C. L. Riedel. 1990. Whey and whey utilization. 2nd Ed., Verlag Th. Mann, Gelsenkirchen-Buer. Germany.

Stack, A. and G. Sillen. 1998. Bactofugation of liquid milks. Nutr. Food Sci. 98:280-282.

Tang, X., S. H. Fint, J. D. Brooks, and R. J. Bennett. 2009. Factors affecting the attachment of micro-organisms isolated from ultrafiltration and reverse osmosis membranes in dairy processing plants. J. Appl. Microbiol. 107:443-451.

Vadi, P. K. and S. S. H. Rizvi. 2001. Experimental evaluation of a uniform transmembrane pressure crossflow microfiltration unit for the concentration of micellar casein from skim milk. J. Memb. Sci. 189:69-82.

Van der Horst, H. C., J. M. K. Timmer, T. Robbertson, and J. Leenders. 1995. Use of nanofiltration for concentration and demineralization in the dairy industry: Model for mass transport. J. Memb. Sci. 104:205-218.

Van Leeuwen, J., H. Freeman, J. Sutherland, and W. Jameson. 1987. European Patent WP 0120879 B1.

Van Reis, R. and A. L. Zydney. 2007. Bioprocess membrane technology. J. Memb. Sci. 297:16-50.

Van Rijn, C. J. and J. Kromkamp. 2001. Method for filtering milk. WO Patent 0209527.

Visvanathan, C. and R. Ben. 1989. Aim, application of an electric field for the reduction of particle and colloidal fouling in cross flow microfiltration. Sep. Sci. Technol. 24:383-398.

Vourch, M., B. Balannec, B. Chaufer, and G. Dorange 2005. Nanofiltration and reverse osmosis of model process waters from the dairy industry to produce water for reuse. Desalination 172:245-256.

Wakeman, R. J. and C. J. Williams. 2002. Additional techniques to improve microfiltration. Sep. Purif. Technol. 26:3-18.

Winston Ho, W. S. and K. K. Sirkar. 1992. In: Membrane Handbook (Ed. W. S. Winston Ho and K. K. Sirkar). Van Nostrand Reinhold, 3-16. 